\title{
Effects of Ag Nanoparticles on Growth and Fat Body Proteins in Silkworms (Bombyx mori)
}

\author{
Xu Meng ${ }^{1}$ Nouara Abdlli ${ }^{1}$ Niannian Wang ${ }^{1}$ Peng L $\ddot{~}^{1} \cdot$ Zhichao Nie $^{1} \cdot$ Xin Dong $^{1}$ \\ Shuang Lu ${ }^{1} \cdot$ Keping Chen ${ }^{1}$
}

Received: 18 February 2017 / Accepted: 17 March 2017 /Published online: 30 March 2017

(C) The Author(s) 2017. This article is published with open access at Springerlink.com

\begin{abstract}
Ag nanoparticles (AgNPs), a widely used non-antibiotic, antibacterial material, have shown toxic and other potentially harmful effects in mammals. However, the deleterious effects of AgNPs on insects are still unknown. Here, we studied the effects of AgNPs on the model invertebrate organism Bombyx mori. After feeding silkworm larvae different concentrations of AgNPs, we evaluated the changes of $B$. mori body weights, survival rates, and proteomic differences. The results showed that low concentrations $(<400 \mathrm{mg} / \mathrm{L})$ of AgNPs promoted the growth and cocoon weights of B. mori. Although high concentrations ( $\geq 800 \mathrm{mg} /$ L) of AgNPs also improved B. mori growth, they resulted in silkworm death. An analysis of fat body proteomic differences revealed 13 significant differences in fat body protein spots, nine of which exhibited significantly downregulated expression, while four showed significantly upregulated expression. Reverse transcription-polymerase chain reaction results showed that at an AgNP concentration of $1600 \mathrm{mg} / \mathrm{L}$, the expression levels of seven proteins were similar to the transcription levels of their corresponding genes. Our results suggest that AgNPs lowered the resistance to oxidative stress, affected cell apoptosis, and induced cell necrosis by regulating related protein metabolism and metabolic pathways in B. mori.
\end{abstract}

Keywords AgNPs · Bombyx mori $\cdot$ Environmental risk · Fat body proteins $\cdot$ Growth

Xu Meng and Nouara Abdlli are co-first authors.

Keping Chen

kpchen@ujs.edu.cn

1 Institute of Life Sciences, Jiangsu University, Zhenjiang, Jiangsu 212013, China

\section{Introduction}

Nanomaterials have very small sizes (1-100 nm) and some special physical and chemical properties. Ag nanoparticles (AgNPs) are some of the most novel and commercialized nanomaterials, and they have strong antibacterial activity. They are widely used in many fields, such as food packaging, medical devices, and cosmetics [1, 2]. However, several studies have implied that they are potentially hazardous [3, 4]. Currently, studies have demonstrated the potential impact of AgNPs on human health and the environment [3, 4]. Artificial nanomaterials have strong binding affinities for biopolymer molecules because of their lipophilic properties, coordination properties, and polarity effects both "in vivo" and in the environment, which have potentially adverse effects on human health and the environment [5-7]. Morones indicated that AgNPs not only exist on the cell membrane surface but can enter the cell interior [8]. The use of AgNPs in food storage may interfere with DNA replication and cause DNA mutations, which may potentially induce DNA denaturation [9]. Moreover, many nanomaterials can also enter the water, atmosphere, and soil, which is a huge potential risk to humans [10]. Studying the toxic effects of AgNPs on the model silkworm Bombyx mori can provide a useful reference for environmental monitoring.

In mammalian studies, nanomaterials entered different tissues and organs through the circulatory system, thereby endangering the safety of the host [11-14]. It was demonstrated that nanomaterials have adverse effects on tissues and organs, such as the brain, midgut, and reproductive organs [12, 13]. Nano-ZnO NPs, AgNPs, and nano-Ti 20 NPs all had toxic effects on algae, zooplankton, and fish [15]. Furthermore, AgNPs showed potential toxicological and neurotoxicological effects in "vivo" and in "vitro" $[11,16,17]$. AgNPs induced slight liver injuries at doses of $125 \mathrm{mg} / \mathrm{kg} /$ day in rats in an oral exposure study [18]. These studies suggest that AgNPs have potent 
cytotoxic effects and may cause oxidative damage, inflammation, DNA damage, and cell apoptosis/necrosis [16, 17, 19].

Nanomaterials have potential risks to the environment, and their hazards are closely related to their concentration, morphology, migration, and transformation processes, as well as environmental conditions [20]. The toxicity of nanomaterials and their environmental risks have become a hot research topic. At present, studies of the toxic effects of AgNPs have mainly been conducted in mammals, while few studies have been conducted in invertebrates. Previous studies have reported that AgNPs can induce Heliothis virescens (tobacco budworm) and Trichoplusia ni (cabbage looper) developmental delay, reductions in adult weight and fecundity, and increased mortality in the predator [21]. B. mori, an important invertebrate model organism, exhibits relatively weak resistance to stress and disease, and it is especially sensitive to chemical pesticides, heavy metals, and other harmful substances [22]. The fat body plays an important physiological role in nutrient storage, metabolic detoxification, and immune regulation [23], and its function is similar to that of the mammalian liver $[24,25]$. As such, it is a more sensitive model organism for monitoring environmental toxins. Studies found that AgNPs at the concentration of $100 \mathrm{ppm}$ were able to produce lethal effects on pupation and adult development, with accumulative hazard in silkworm [26]. Here, we examined the effects of different concentrations of AgNPs on the growth of B. mori, and we also investigated the toxic effects of AgNPs by analyzing fat body proteomics in B. mori.

\section{Material and Methods}

\section{Insect Strains}

The larvae of B. mori (strain: Jingsong $\times$ Haoyue) were maintained in our laboratory and reared on mulberry (Morus) leaves under a 12-h light/12-h dark cycle. The larvae were fed three times per day.

\section{Chemicals}

Silver nanoparticle (AgNP) powder was purchased from Suzhou Nord Derivatives Pharm-tech Co. Ltd. (Suzhou, China). Characterization of AgNPs (diameter $30 \mathrm{~nm}$ ) and AgNP stock solution was synthesized as previously described [27]. The AgNPs were powdered using an ultrasonic technique for $20 \mathrm{~min}$ and mixed by mechanical vibration. To obtain the UV-vis spectrum of silver nanoparticles, powdered silver nanoparticles were dispersed in deionized water at 50 and $25 \mathrm{mg} / \mathrm{L}$ and scanned from 300 to $800 \mathrm{~nm}$ using a spectrophotometer (Synergy H4, Bio-Tek, USA). The size, shape, and dispersion of AgNPs were further confirmed by transmission electron microscopy (TEM, JEM-2100, JEOL, Japan).

\section{Treatments}

Mulberry leaves were soaked in different concentrations of AgNPs. The soaked leaves were dried naturally at room temperature, and they were fed continuously three times per day to newly exuviated fourth- and fifth-instar larvae until molting. Control larvae were fed mulberry leaves soaked in water. All the larvae were maintained at $25 \pm 0.5^{\circ} \mathrm{C}$ and a relative humidity of $70-75 \%$. Each treatment was replicated three times with 30 larvae. Furthermore, the fourth-instar silkworms were divided into two classes or seven groups. Class 1 received low concentrations of AgNPs, and it contained four treatment groups (double-distilled (dd) $\mathrm{H}_{2} \mathrm{O}$ and 100, 200, and $400 \mathrm{mg} / \mathrm{L}$ AgNPs). Class 2 received high concentrations of AgNPs, and it contained three treatment groups $(800,1600$, and $3200 \mathrm{mg} / \mathrm{L}$ AgNPs). An analytical balance was used to measure the weights of the silkworms, and each value is the mean of three replicates.

\section{Protein Sample Preparation}

Twenty silkworms were selected randomly for fat body extraction, and proteins were extracted with phenol. The silkworm fat body from the control $\left(\mathrm{ddH}_{2} \mathrm{O}\right)$ and treatment (AgNPs) groups was ground in liquid nitrogen with homogenization buffer $(20 \mathrm{mM}$ Tris- $\mathrm{HCl}, \mathrm{pH} 7.5$, $250 \mathrm{mM}$ sucrose, $10 \mathrm{mM}$ ethylenediaminetetraacetic acid, $1 \mathrm{mM}$ phenylmethylsulfonyl fluoride, $1 \mathrm{mM}$ beta-mercaptoethanol, and $1 \%(v / v)$ Triton X-100), as described by Cilia et al. [28]. Then, the mixture was vortexed for $30 \mathrm{~min}$ and centrifuged at $21000 \times \mathrm{g}$ for $20 \mathrm{~min}$. The supernatant was added to an equal volume of Tris-saturated phenol to precipitate the proteins. The phenol layer containing the proteins was collected, incubated with a methanol solution (containing $100 \mathrm{mM}$ ammonium acetate), and centrifuged at $21000 \times \mathrm{g}$ for $20 \mathrm{~min}$ to pellet the proteins. The pellet was washed with cold acetone (containing $1 \mathrm{mM}$ dithiothreitol (DTT)); lyophilized, dissolved in a solution containing $7 \mathrm{M}$ urea, $2 \mathrm{M}$ thiourea, 4\% (w/v) CHAPS, and 1\% (w/ v) DTT; and centrifuged at $21000 \times g$ for $20 \mathrm{~min}$. The supernatant, as the sample of total fat body proteins, was pooled and stored at $-80{ }^{\circ} \mathrm{C}$ for later use. The protein concentration was determined using the $\mathrm{RC}$ DC'м Kit (Bio-Rad, Hercules, CA, USA). 


\section{Two-Dimensional Electrophoresis}

Two-dimensional electrophoresis was performed with a $17-\mathrm{cm}$ (linear, $\mathrm{pH}$ 4-7) immobilized $\mathrm{pH}$ gradient (IPG gel) strip (Bio-Rad), as described by Liang et al. [29]. Total fat body proteins $(3 \mathrm{mg}$ ) were loaded onto the IPG strip for $12 \mathrm{~h}$, and isoelectric focusing was performed at $20{ }^{\circ} \mathrm{C}$ with a voltage gradient of $100 \mathrm{~V}$ for $1 \mathrm{~h}, 300 \mathrm{~V}$ for $1 \mathrm{~h}, 1000 \mathrm{~V}$ for $1 \mathrm{~h}$, $8000 \mathrm{~V}$ for $1 \mathrm{~h}$, and $10,000 \mathrm{~V}$ for 40,000 $\mathrm{Vh}$, and then, it was continued at $500 \mathrm{~V}$. The IPG gel strip was equilibrated for 15 min with equilibration buffer $(6 \mathrm{M}$ urea, $0.375 \mathrm{M}$ TrisHCI, 20\% (v/v) glycerol, 2\% (w/v) sodium dodecyl sulfate (SDS), and 2\% (w/v) DTT), and then, it was equilibrated for another $15 \mathrm{~min}$ in the same equilibration buffer without DTT, but containing $2.5 \%(w / v)$ iodoacetamide. The equilibrated strip was sealed on the top of a $12 \%$ SDS-polyacrylamide gel and subjected to electrophoresis. Proteins were visualized by staining with $0.1 \%$ Coomassie brilliant blue R-250, and they were scanned with a high-precision scanner (ImageScanner III, GE Healthcare Life Sciences, Pittsburgh, PA, USA) at a resolution of 300 dpi. Spot analysis was performed using ImageMaster (version 7.0, GE Healthcare Life Sciences). Triplicate experiments were conducted for each sample. The intensity ratio of the corresponding spots in different gels was calculated, and spots with ratio $\geq 2$ and ANOVA $\leq 0.05$ were defined as quantitatively different spots.

\section{RNA Extraction and Transcriptional Analysis}

The fat bodies of the fifth-instar larvae in each group were dissected, immediately frozen in liquid $\mathrm{N}_{2}$, and stored at $-80{ }^{\circ} \mathrm{C}$ for later use. Total RNA was extracted using TRIzol reagent (Invitrogen, Carlsbad, CA, USA). RNA was reverse transcribed from $3 \mu \mathrm{g}$ of total RNA using Moloney Murine Leukemia Virus Reverse Transcriptase (Vazyme, Nanjing, China) according to the manufacturer's instructions. NCBI Primer-BLAST (https://blast.ncbi.nlm.nih.gov/Blast.cgi) was used to design quantitative real-time polymerase chain reaction (qPCR) primers for important differentially expressed genes (Table 1); $\alpha$-tubulin was used as the reference gene. qPCR was performed using a 7300 Fast System (Applied Biosystems, Foster City, CA, USA) with a SYBR Green Master Mix kit (Vazyme, Nanjing), according to the manufacturer's instructions. The data were analyzed with the SDSS software package (Version 16.0, SPSS Inc., Chicago, IL, USA). All samples were measured independently three times.

\section{Data Analysis}

Statistical analyses were conducted using SPSS for Windows, Version 16.0. Data were expressed as the mean \pm standard deviation (SD). One-way analysis of variance was conducted to compare the differences of the means among multi-group data. Dunnett's test was performed when each dataset was compared with the control data. Statistical significance for all tests was judged at a probability level of $0.05(P<0.05)$.

\section{Results}

\section{Characterization of AgNPs}

The AgNPs employed in our study exhibited spherical characteristics with absorbance spectra at $\lambda_{\max } 400 \mathrm{~nm}$ (Fig. 1a).

Table 1 Primer sequences used in the qPCR

\begin{tabular}{llllll}
\hline Gene name & \multicolumn{2}{l}{ Primer sequence $\left(5^{\prime}-3^{\prime}\right)$} & & & $\begin{array}{l}\text { Length of } \\
\text { product (bp) }\end{array}$ \\
\hline P1 & F: & GTCCATCGACAGCGAGGAAT & R: & GGGCGTTCACATCCTCAGAA & 167 \\
P4 & F: & GCTCCACTCACTGAAACCGA & R: & GGAACCACCGTTTTGCTCC & 203 \\
P5 & F: & ACGGTTGTTCAAGTGCCAGA & R: & AGGAGGGTGGATCCGAATGA & 181 \\
P6 & F: & CCGGAGGCTCATCAGAAATCA & R: & TTCACATCACCCCCTTCTGC & 164 \\
P7 & F: & GAGAGCGATCGGAAAAGGCT & R: & TAGAAGGGCTCATGCTGTCC & 117 \\
P8 & F: & CCCCCGTGTTGGAAACAAC & R: & ACGAAGAACATGACGTCGCT & 190 \\
P9 & F: & ATGTGGGCATCAAATGTGCG & R: & AGCATGAGCATGACGTCCAA & 206 \\
P12 & F: & GGAAAGCTGACATGGGGTGA & R: & AAGCCTTCACTTTGGGCTGT & 106 \\
P13 & F: & CAATGCCTTAGCAGTGCGAC & R: & TCGGCTTTCGTCTTCAGGAG & 239 \\
\hline
\end{tabular}



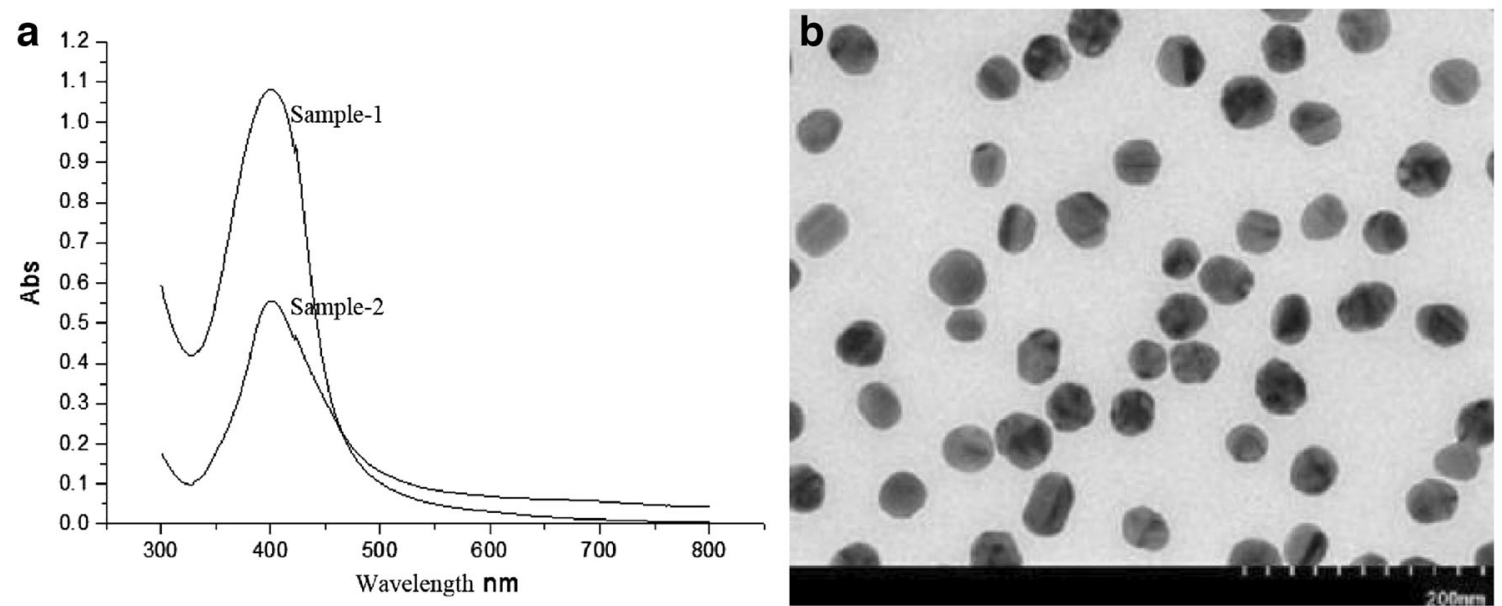

Fig. 1 Characterization of AgNPs. a UV-visible absorption spectra of AgNPs powder dissolved in deionized water at $50 \mathrm{mg} / \mathrm{L}$ (sample 1 ) and $25 \mathrm{mg} / \mathrm{L}$ (sample 2). Narrow peak confirms the small size of the particles. b TEM image shows that the AgNPs exhibit the homogeneous distribution in size

TEM images also substantiated the spherical silver nanoparticles with an approximate size of $30 \mathrm{~nm}$ (Fig. 1b). These data clearly indicated that experimental AgNPs exhibited a homogeneous dispersion in aqueous solutions.

\section{Effects of Feeding Different Concentrations of AgNPs on Silkworm Growth}

Silkworms were fed AgNPs from the fourth instar, and then, their body weights were measured. The results showed an increasing trend of the body weights with different concentrations of AgNPs (Fig. 2a and Table 2). The growth of B. mori that were fed $<400 \mathrm{mg} / \mathrm{L} \mathrm{AgNPs} \mathrm{did} \mathrm{not} \mathrm{change} \mathrm{significantly}$ during the fourth instar after $48 \mathrm{~h}$, while their body weights increased slightly when fed $>800 \mathrm{mg} / \mathrm{L} \mathrm{AgNPs}$. The body weights increased most significantly after the silkworms were

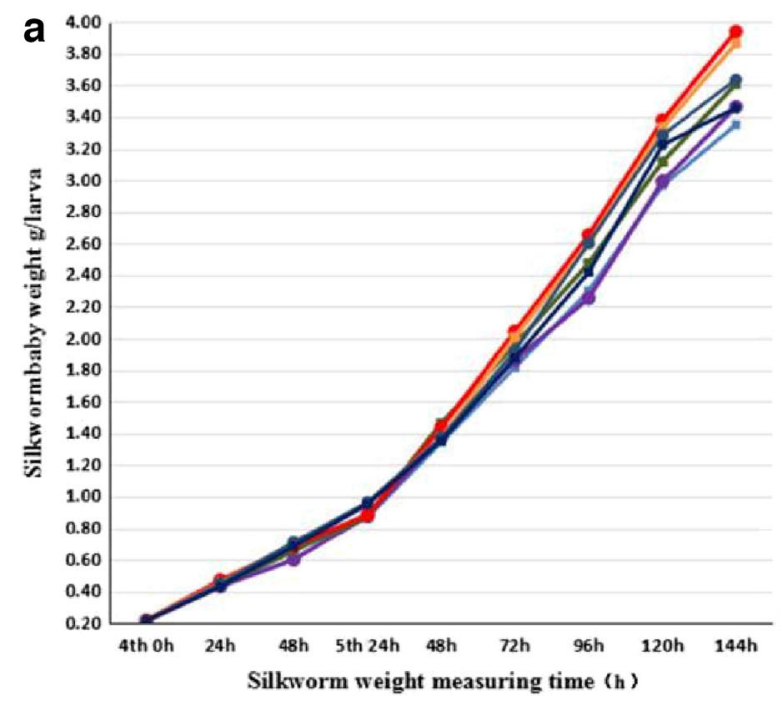

Fig. 2 Effects of different concentrations of AgNPs on the body weights of silkworms. a Average weights of fourth- and fifth-instar silkworms from 0 to 48 and 24 to $144 \mathrm{~h}$, respectively. b Morphological fed $400 \mathrm{mg} / \mathrm{L}$ AgNPs for $144 \mathrm{~h}$ (Fig. 2b). The body weights of B. mori increased slowly at AgNP concentrations $\leq 200 \mathrm{mg} / \mathrm{L}$, but the growth-promoting effect was diminished at higher ( $\geq 800 \mathrm{mg} / \mathrm{L}$ ) AgNP concentrations (Table 2).

\section{Effects of AgNPs on Silkworm Survival Rates and Cocoon Shell Weights}

AgNPs have no lethal effects on silkworm larvae at low concentrations $(\leq 400 \mathrm{mg} / \mathrm{L})$. The survival rates and cocoon shell weights of the silkworms were analyzed at $\geq 800 \mathrm{mg} / \mathrm{L} \mathrm{AgNP}$ concentrations (Table 3 and Fig. 3). The results indicated that the larvae began to die when treated with $800 \mathrm{mg} / \mathrm{L} \mathrm{AgNPs,}$ and they exhibited increased weight of the cocoon shells and significantly decreased moth rate. At $\geq 800 \mathrm{mg} / \mathrm{L} \mathrm{AgNP}$ concentrations, the larval survival rates, cocoon shell weights, and

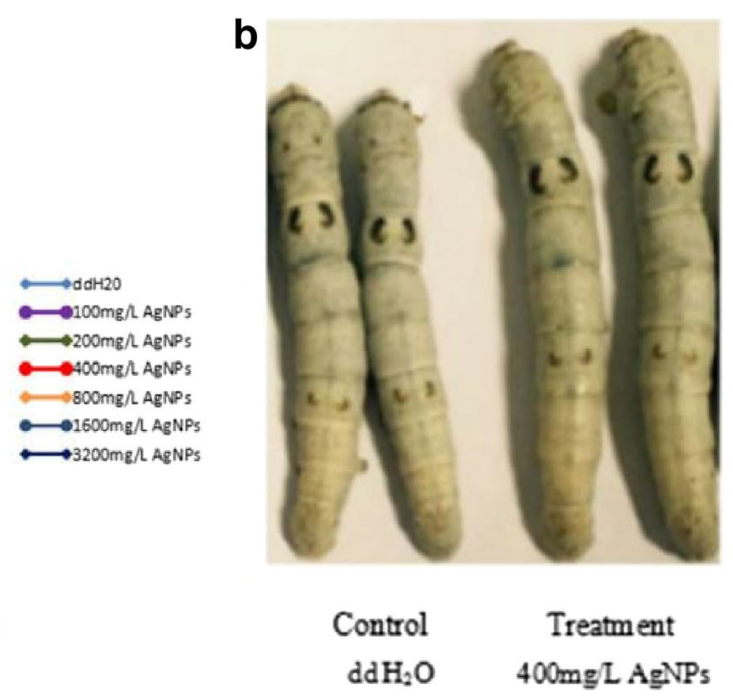

abnormalities of silkworms after feeding AgNPs. The body weights of the control $\left(\mathrm{ddH}_{2} \mathrm{O}\right)$ group differed from that of the treatment groups (400 mg/L AgNPs) during the fifth instar at $144 \mathrm{~h}$ 


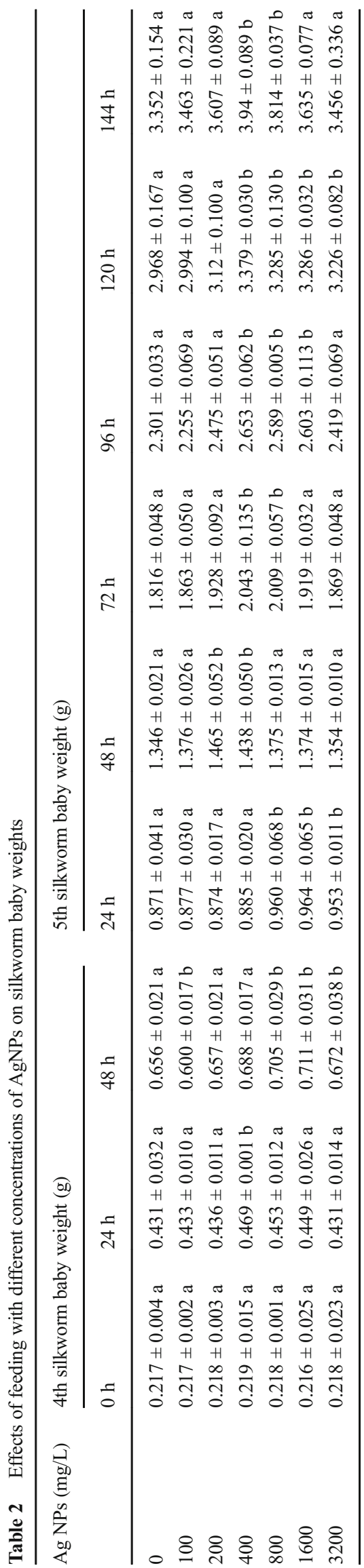

the moth rates decreased remarkably, but the weights of the cocoon shells increased. At $3200 \mathrm{mg} / \mathrm{L}$ AgNP concentrations, the weight of the cocoon shells increased, but the moth rate was only $50 \pm 10 \%$. The results showed that high concentration $(\geq 800 \mathrm{mg} / \mathrm{L})$ of AgNPs increased weight of the cocoon shells of silkworms, which resulted in larval death.

\section{Effects of AgNPs on the Fat Body Proteome in Silkworms}

As shown in Fig. 4, the software analysis showed that there were 13 significant differences between the fat body protein spots of the control group and the treatment group $(1600 \mathrm{mg} / \mathrm{L}$ $\mathrm{AgNPs})$. Eleven proteins were expressed in both groups, and two proteins were only expressed in the control group (Table 4).

\section{qPCR for Differentially Expressed Protein Validation}

cDNA was isolated from fifth-instar larvae and used as template after the larvae were fed AgNPs for $144 \mathrm{~h}$. qPCR was performed to examine the expression of genes encoding the fat body proteins that were differentially expressed between the control group and the AgNP groups ( 800 and $1600 \mathrm{mg} / \mathrm{L}$ ) (Fig. 5). Compared with the control group, the calexcitin-2-like (A) and cytosolic non-specific dipeptidase (C) genes were downregulated significantly, and glutathione S-transferase s1 (GSTs1) (D) genes and $A K(\mathrm{E})$ were upregulated significantly in the treatment groups, which is consistent with the corresponding protein expression levels. The expression of the LP-C6 (B) did not differ significantly between the 800 and $1600 \mathrm{mg} / \mathrm{L}$ AgNP groups. The expression of the S-formylglutathione hydrolase gene $(\mathrm{G})$ was downregulated significantly in the $800 \mathrm{mg} / \mathrm{L} \mathrm{AgNP}$ group, and it was downregulated slightly in the $1600 \mathrm{mg} / \mathrm{L} \mathrm{AgNP}$ group. The expression of the genes encoding juvenile hormone binding protein (JHBP) (F) and isocitrate dehydrogenase $(\mathrm{H})$ was not significantly changed in the $800 \mathrm{mg} / \mathrm{L} \mathrm{AgNP}$ group, but it was upregulated significantly in the $1600 \mathrm{mg} / \mathrm{L}$ AgNP group. The expression of the gene encoding $L P-C 12$ (I) did not differ significantly between the control and treatment groups. The expression levels of seven genes were consistent with those of their corresponding protein spots following treatment with $1600 \mathrm{mg} / \mathrm{L}$ AgNPs. There were no differences in the expression levels of the genes encoding the other six protein spots (Fig. 5).

\section{Discussion}

In the present study, we observed that AgNPs promoted the growth of silkworms and induced their death. To determine the action mechanism of AgNPs, we identified seven protein spots that were differentially expressed following treatment with $1600 \mathrm{mg} / \mathrm{L}$ AgNPs. Furthermore, a functional analysis of the significantly differentially expressed proteins indicated 
Table 3 Effects of different concentrations of AgNPs on silkworm survival rate and cocoon shell weights

\begin{tabular}{llllllrr}
\hline AgNPs (mg/L) & Silkworm $^{\mathrm{a}}$ & Dia $^{\mathrm{a}}$ & Cocoon $^{\mathrm{a}}$ & $\begin{array}{l}\text { Cocoon shells } \\
\text { weight }(\mathrm{g})^{\mathrm{a}}\end{array}$ & Dead cocoon $^{\mathrm{a}}$ & Moth $^{\mathrm{a}}$ & \begin{tabular}{l} 
Moth $_{\text {rate }^{\mathrm{a}}(\%)}$ \\
\hline 0
\end{tabular} \\
\hline 30 & 0 & 30 & $0.3347 \pm 0.001 \mathrm{a}$ & 1 & 29 & 96.67 \\
0 & 30 & 0 & 30 & $0.3355 \pm 0.001 \mathrm{a}$ & 0 & 30 & 100.00 \\
0 & 30 & 0 & 30 & $0.3339 \pm 0.001 \mathrm{a}$ & 1 & 29 & 96.67 \\
800 & 30 & 1 & 29 & $0.349 \pm 0.001 \mathrm{~b}$ & 5 & 24 & 80.00 \\
800 & 30 & 0 & 30 & $0.3486 \pm 0.001 \mathrm{~b}$ & 4 & 26 & 86.67 \\
800 & 30 & 1 & 29 & $0.3494 \pm 0.001 \mathrm{~b}$ & 4 & 25 & 83.33 \\
1600 & 30 & 6 & 24 & $0.3513 \pm 0.001 \mathrm{~b}$ & 6 & 18 & 60.00 \\
1600 & 30 & 7 & 23 & $0.3519 \pm 0.001 \mathrm{~b}$ & 7 & 18 & 60.00 \\
1600 & 30 & 5 & 25 & $0.3507 \pm 0.001 \mathrm{~b}$ & 5 & 20 & 66.67 \\
3200 & 30 & 9 & 21 & $0.3836 \pm 0.001 \mathrm{~b}$ & 6 & 15 & 50.00 \\
3200 & 30 & 11 & 19 & $0.3842 \pm 0.001 \mathrm{~b}$ & 7 & 12 & 40.00 \\
3200 & 30 & 7 & 23 & $0.3829 \pm 0.001 \mathrm{~b}$ & 6 & 17 & 56.67 \\
\hline
\end{tabular}

${ }^{\text {a }}$ Results are expressed as mean $\pm \mathrm{SD}$ that $\mathrm{AK}$ is a phosphokinase that plays critical roles in the metabolism, storage, and utilization of energy in invertebrates [30]. In addition, AK may play an important role in the insect immune response and environmental adaptation. Kang showed that the expression of $\mathrm{AK}$ in the midgut of $\mathrm{NB}$ and BC8 larvae, which are resistant to $B$. mori nuclear polyhedrosis virus, is higher than that of 306 larvae, indicating that $\mathrm{AK}$ protects silkworm larvae against viral infection [31]. GSTs1 is a multifunctional enzyme in vivo, and it plays major roles in protecting against oxidative damage, as well as in antioxidant processes, detoxification, and metabolism, including GSH-independent peroxidase activity $[32,33]$. A study found that the mercapto group of biological systems may be involved in the transport of AgNPs [34]. GST plays an important role in the detoxification of insecticides [35]. The

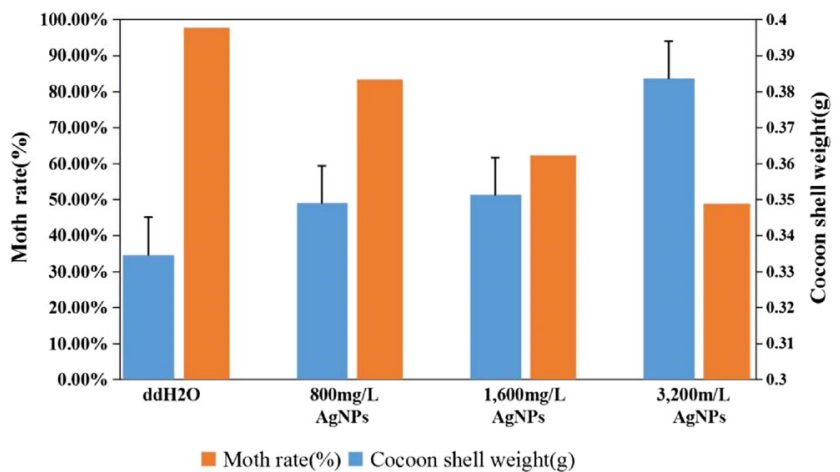

Fig. 3 Effects of high concentrations of AgNPs on the cocoon shell weights and moth rates. With increasing concentrations of AgNPs, the cocoon shell weights of the silkworms showed an increase tendency, while moth rates gradually decreased. Statistical significance for all tests was judged at a probability level of $0.05(P<0.05)$ expressions of AK and GSTs1 were upregulated after silkworms being fed AgNPs. In the present study, this may be related to an emergency response that induced toxic effects and immune responses in the presence of high concentrations of AgNPs in silkworms.

LP-c is a low-molecular-weight $(30 \mathrm{kDa})$ protein that is synthesized in the fat body. It is an important storage protein during silkworm growth and development. It was shown that LP-c could bind to the ecdysone receptor-B1 (EcR-B1) and thus inhibit the binding of EcR-B1 to ultraspiracle (USP), leading to the failure of EcR-B1 in activating the expression of downstream genes, thereby inhibiting apoptosis [36]. This $30 \mathrm{kDa}$ protein can prolong life and inhibit programmed cell death in insects [37]. Heat shock protein 19.9 (HSP 19.9) is a member of the small HSP family, which plays an important role in protecting cells from heat-induced damage [38]. It is also involved in the protection against heat stress-induced apoptosis and other phenomena [39]. These results are similar to those obtained in Drosophila melanogaster [40]. HSPs induce cell growth and differentiation in the presence of oxidative stress in mammalian cells [41]. The expressions of LP-c and HSP 19.9 were downregulated after silkworms being treated with AgNPs. The results showed that when the concentration of AgNPs reached $1600 \mathrm{mg} / \mathrm{L}$, the expression of the LP-c protein was altered, and the apoptosis and death of silkworm cells appeared. Cytosolic non-specific dipeptidase 2 (CNDP2) is a dipeptide metalloproteinase that catalyzes the cleavage of dipeptide B-alanyl-L-histidine [42]. The CNDP2 gene encodes a non-specific carnosinase that has a high affinity for Cys-Gly in the $\gamma$-glutamyl cycle, and it is involved in the biosynthesis of GSH [43]. GSH acts as a detoxification agent in the body. Thus, the downregulated expression of the 

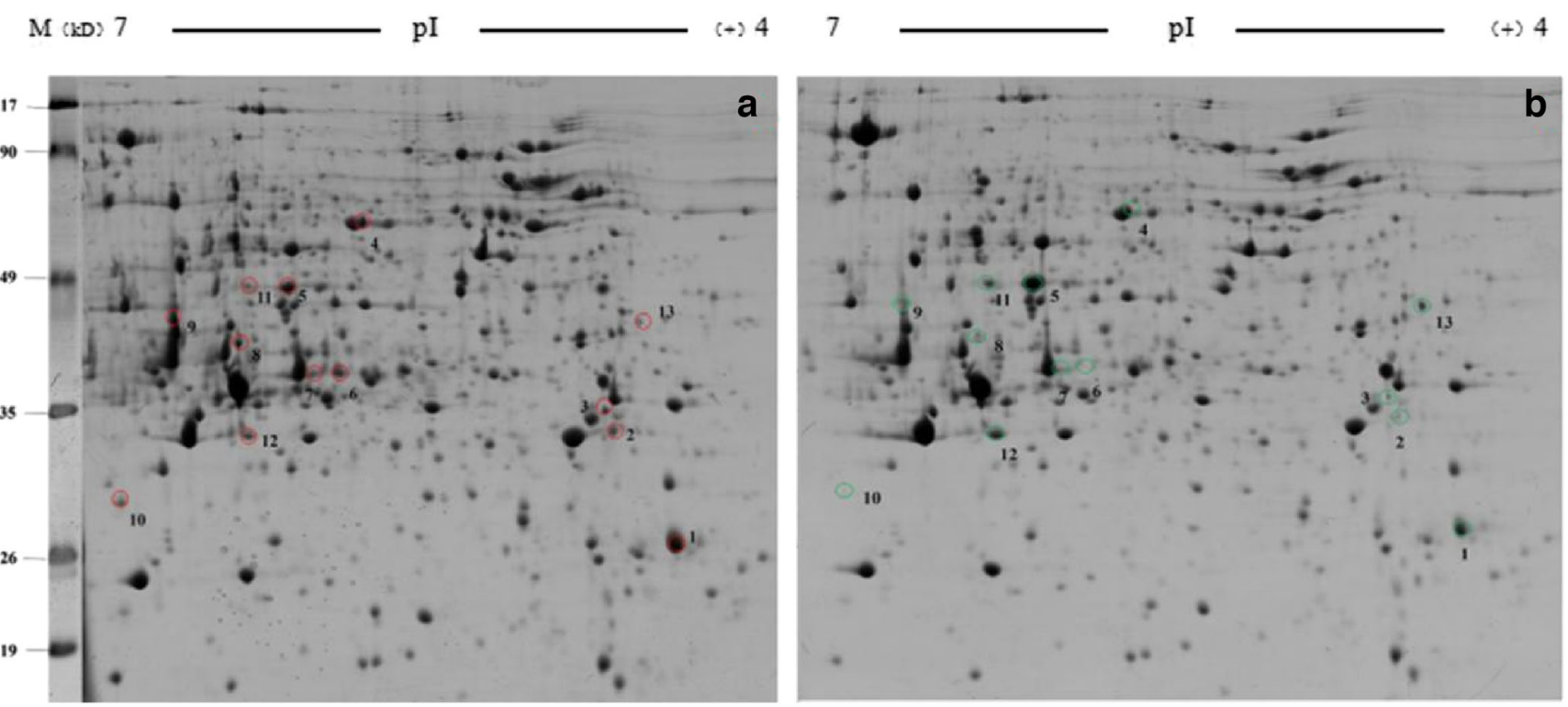

Fig. 4 Two-dimensional electrophoresis results of fat body proteins. a The control group treated with $\mathrm{ddH}_{2} \mathrm{O}$. b The group treated with $1600 \mathrm{mg} / \mathrm{L}$ AgNPs. Numbered spots represent differentially expressed proteins

CNDP2 protein will decrease GSH synthesis, and detoxification, and result in the death of silkworms.

Calexcitin, a signaling protein that binds calcium and GTP, inhibits potassium channels. Calexcitin, which contains an EF-hand domain pair, is involved in binding to metal ions and increasing the diversity of the regulation of calcium-binding proteins [44]. After silkworms were fed AgNPs, the expression of calexcitin was downregulated, which affects the cell membrane potential, nerve conduction, and the signal pathways of silkworms.

Table 4 Identification of differentially regulated proteins in the control $\left(\mathrm{ddH}_{2} \mathrm{O}\right)$ and treatment $(1600 \mathrm{mg} / \mathrm{L}$ AgNPs $)$ groups

\begin{tabular}{|c|c|c|c|c|c|c|c|c|}
\hline \multirow{2}{*}{$\begin{array}{l}\text { Spot no. }^{\text {a }} \\
1\end{array}$} & \multirow{2}{*}{$\begin{array}{l}\text { Protein ID } \\
\text { gi|512908327 }\end{array}$} & \multirow{2}{*}{$\begin{array}{l}\text { Name } \\
\text { Calexcitin-2-like }\end{array}$} & \multirow{2}{*}{$\begin{array}{l}\text { Gene name } \\
/\end{array}$} & \multicolumn{2}{|c|}{$\begin{array}{l}\text { Theoretical } \\
\mathrm{MW}^{\mathrm{b}}(\mathrm{kDa}) / \mathrm{pI}^{\mathrm{c}}\end{array}$} & \multirow{2}{*}{$\begin{array}{l}\text { ANOVA } P \text { value } \\
2.09 \mathrm{E}-04\end{array}$} & \multirow{2}{*}{$\begin{array}{l}\text { Fold change }^{\mathrm{d}} \\
2.03\end{array}$} & \multirow{2}{*}{$\begin{array}{c}\text { Express }^{e} \\
\downarrow\end{array}$} \\
\hline & & & & 23.56 & 5.09 & & & \\
\hline 2 & gi|13195043 & Fibroin light chain, partial & Fib-l & 24.83 & 4.53 & 0.00108697 & 2.28 & $\downarrow$ \\
\hline 3 & gi|512931543 & Ubiquitin carboxyl-terminal hydrolase & / & 25.1 & 5.02 & $2.82 \mathrm{E}-04$ & 2.01 & $\downarrow$ \\
\hline 4 & gi|512915932 & Cytosolic non-specific dipeptidase & / & 58.83 & 6.15 & $6.94 \mathrm{E}-05$ & 2.27 & $\downarrow$ \\
\hline 5 & gi|112983926 & Arginine kinase & $A K$ & 32.50 & 7.23 & $1.36 \mathrm{E}-05$ & 0.43 & $\uparrow$ \\
\hline 6 & gi|512915980 & S-formylglutathione hydrolase & / & 32.13 & 5.65 & 0.00128389 & 5.25 & $\downarrow$ \\
\hline 7 & gi|827538302 & Low molecular $30 \mathrm{kDa}$ lipoproteinPBMHP-12 & $L p-c 12$ & 21.83 & 8.61 & 0.0338263 & 6.38 & $\downarrow$ \\
\hline 8 & gi|225905552 & Low molecular lipoprotein 30K pBmHPC-6 & $L p-c 6$ & 29.82 & 5.92 & 0.0464862 & 2.73 & $\downarrow$ \\
\hline 9 & gi|87248167 & Isocitrate dehydrogenase, partial & / & 46.55 & 6.24 & 0.00947802 & 11.25 & $\downarrow$ \\
\hline 10 & gi|112983420 & Heat shock protein hsp 19.9 & Hsp19.9 & 19.94 & 6.53 & $2.40 \mathrm{E}-04$ & 2.67 & $\downarrow$ \\
\hline 11 & gi|827541166 & Arginine kinase & $A K$ & 40.31 & 5.87 & $3.57 \mathrm{E}-04$ & 0.27 & $\uparrow$ \\
\hline 12 & gi|112983028 & Glutathione S-transferase sigma 1 & GSTs 1 & 23.60 & 5.98 & 0.00239861 & 0.48 & $\uparrow$ \\
\hline 13 & gi|6016405 & Juvenile hormone-binding protein & $J H B P$ & 2.15 & 6.02 & $2.89 \mathrm{E}-05$ & 0.44 & $\uparrow$ \\
\hline
\end{tabular}

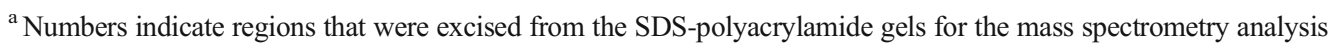

${ }^{\mathrm{b}}$ Molecular weight

${ }^{\mathrm{c}}$ Isoelectric point

${ }^{\mathrm{d}}$ Fold change $=$ control $/$ treatment

e Upregulated expression “ $\uparrow$ ”; downregulated expression“ $\downarrow$ ” 


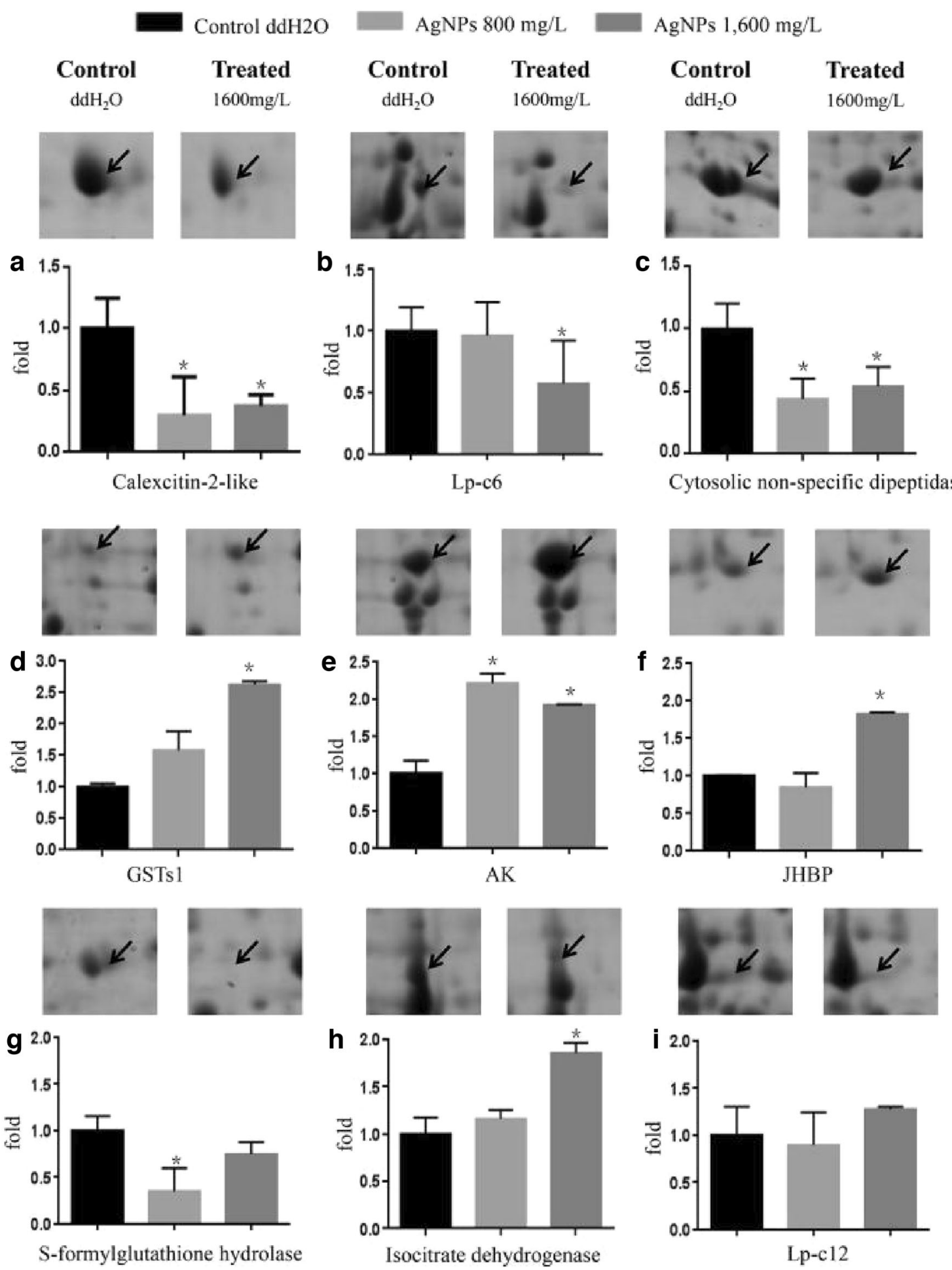

Fig. 5 Differential expressed proteins and the expression of their corresponding genes as measured by qPCR. Arrows indicate significantly differentially expressed proteins. The results of the qPCR for genes in the control group are shown in black, while those of the 800

Low-molecular-weight JHBPs are specific vectors for juvenile hormone $(\mathrm{JH})$ in the hemolymph of butterflies and moths. As hormone signal transporter, JHBPs have a profound impact on the growth and development of insects [45]. and $1600 \mathrm{mg} / \mathrm{L}$ AgNP groups are shown in light gray and dark gray, respectively. The experiments were repeated three times, and statistically significant differences (mean $\pm \mathrm{SD}, P<0.05$ ) are indicated

Previous reports suggested that $\mathrm{JH}$ binds to three types of JHBPs, including lipoproteins, hexamers, and low-molecular-weight proteins of approximately $30 \mathrm{kDa}$ [46-48]. Adding JH to larvae can extend the period of eating 
Fig. 6 The biological consequences of silkworm exposure to AgNPs
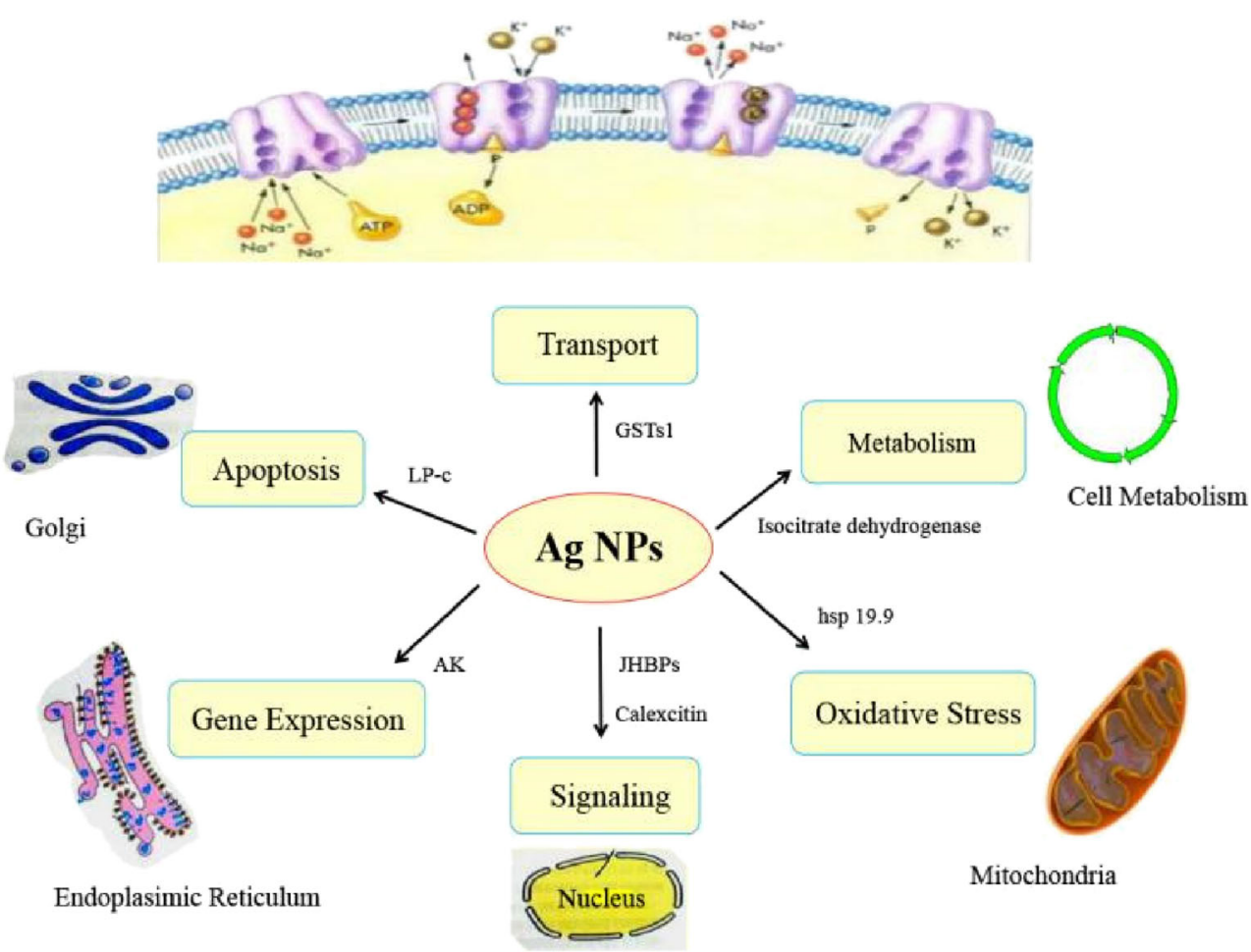

mulberry leaves, the synthesis of fibroin, and the weights of the cocoon shells [49]. In our study, the period of eating mulberry leaves was extended. Therefore, we speculate that the increase weights of the cocoon shells may be related to the upregulation of expression of JHBPs after treatment with AgNPs. It may also be associated with the upregulation of cytosolic non-specific dipeptidase and AK protein expression, which results in the increased storage and utilization of carbohydrates in silkworms. Previous research also showed that AgNPs exhibit the presence of certain growth stimulant activity and can increase the silk yield [50]. Moreover, the results of a Kyoto Encyclopedia of Genes and Genomes analysis showed that isocitrate dehydrogenase and S-formylglutathione hydrolase, the key rate-limiting enzymes in the carbon cycling pathway, were both downregulated after the addition of AgNPs, which results in the slower use of carbohydrates by fat bodies, as well as associated metabolic changes.

In the present study, growth-inhibiting and toxic effects of AgNPs on silkworms were observed at the individual level. We found that AgNPs influenced the functions of the metabolic cycle, as well as signal transduction, apoptosis, and ion transport (Fig. 6). AgNPs could influence carbon regulatory proteins during metabolism, thereby weakening their metabolic function and increasing energy storage and utilization. AgNPs also can reduce the ability of silkworms to withstand oxidative stress, interfere with programmed cell death, and attenuate the expression of detoxification proteins. Overall, AgNPs have large potential toxic effects on human health and the environment; therefore, they should be used with caution.
Acknowledgements This research was supported partly by research grants from the National Natural Science Foundation of China (31572467) and Research Fund for International Young Scientists of China (31550110210).

Open Access This article is distributed under the terms of the Creative Commons Attribution 4.0 International License (http:// creativecommons.org/licenses/by/4.0/), which permits unrestricted use, distribution, and reproduction in any medium, provided you give appropriate credit to the original author(s) and the source, provide a link to the Creative Commons license, and indicate if changes were made.

\section{References}

1. Suh WH, Suslick KS, Stucky GD, Suh YH (2009) Nanotechnology nanotoxicology, and neuroscience. Prog Neurobiol 87:133-170

2. Seal S, Karn B (2014) Safety aspects of nanotechnology based activity. Saf Sci 63:217-225

3. Sekhon BS (2014) Nanotechnology in agri-food production: an overview. Nanotechnol Sci Appl 8:31-53

4. Stensberg MC, Wei Q, McLamore ES, Porterfield DM, Wei A, Sepúlveda MS (2017) Toxicological studies on silver nanoparticles: challenges and opportunities in assessment, monitoring and imaging. Nanomedicine 6:879-988

5. Tang H, Wang D, Ge X (2004) Environmental nanopollutants (ENP) and aquatic micro interfacial processes. Water Sci Technol 50:103-109

6. Du J, Wang S, You H, Zhao X (2013) Understanding the toxicity of carbon nanotubes in the environment is crucial to the control of nanomaterials in producing and processing and the assessment of health risk for human: a review. Environ Toxicol Pharmacol 36:5162 
7. Khajeh M, Sanchooli E (2011) Silver nanoparticles as a new solidphase adsorbent and its application to preconcentration and determination of lead from biological samples. Biol Trace Elem Res 143: $1856-1864$

8. Morones JR, Elechiguerra JL, Camacho A, Holt K, Kouri JB, Ramirez JT, Yacaman MJ (2005) The bactericidal effect of silver nanoparticles. Nanotechnology 16:2346-2353

9. Satapathy SR, Mohapatra P, Das D, Siddharth S, Kundu CN (2015) The apoptotic effect of plant based nanosilver in colon cancer cells is a 553 dependent process involving ROS and JNK cascade. Pathol Oncol Res 21:405-411

10. Wiesner MR, Lowry GV, Alvarez P, Dionysiou D, Biswas P (2006) Assessing the risks of manufactured nanomaterials. Environ Sci Technol 40:4336-4345

11. Hadrup N, Lam HR (2014) Oral toxicity of silver ions, silver nanoparticles and colloidal silver - a review. Regul Toxicol Pharmacol 68:1-7

12. Zoroddu MA, Medici S, Ledda A, Nurchi VM, Lachowicz JI, Peana M (2014) Toxicity of nanoparticles. Curr Med Chem 21: $3837-3853$

13. Hutz RJ, Carvan MJ, Larson JK, Liu Q, Stelzer RV, King-Heiden TC, Baldridge MG, Shahnoor N, Julien K (2014) Familiar and novel reproductive endocrine disruptors: xenoestrogens, dioxins and nanoparticles. Curr Trends Endocinol 7:111-122

14. Heydrnejad MS, Samani RJ, Aghaeivanda S (2015) Toxic effects of silver nanoparticles on liver and some hematological parameters in male and female mice (Mus musculus). Biol Trace Elem Res 165:1-6

15. Wang J, Wang WX (2014) Significance of physicochemical and uptake kinetics in controlling the toxicity of metallic nanomaterials to aquatic organisms. J Zhejiang Univ-Sc A 15:573-592

16. Lima R, Seabra AB, Durán N (2012) Silver nanoparticles: a brief review of cytotoxicity and genotoxicity of chemically and biogenically synthesized nanoparticles. J Appl Toxicol 32:867-879

17. Au C, Mutkus L, Dobson A, Riffle J, Lalli J, Aschner M (2007) Effects of nanoparticles on the adhesion and cell viability on astrocytes. Biol Trace Elem Res 120:248-256

18. Kim YS, Song MY, Park JD, Song KS, Ryu HR, Chung YH, Chang HK, Lee JH, Oh KH, Kelman BJ, Hwang IK, Yu IJ (2010) Subchronic oral toxicity of silver nanoparticles. Part Fibre Toxicol 7:20-31

19. Zhang TL, Wang LM, Chen Q, Chen CY (2014) Cytotoxic potential of silver nanoparticles. Yonsei Med J 55:283-291

20. Lungu M, Neculae A, Bunoiu M, Biris C (2015) Nanoparticles' promises and risks. Springer International Publishing, Switzerland

21. Afrasiabi Z, Popham HJR, Stanley D, Suresh D, Finley K, Campbell J, Kannan R, Upendran A (2016) Dietary silver nanoparticles reduce fitness in a beneficial, but not pest, insect species. Arch Insect Biochem 93:190-201

22. Zou X, Shi J, Zhang H (2014) Coexistence of silver and titanium dioxide nanoparticles: enhancing or reducing environmental risks. Aquat Toxicol 154:168-175

23. Arrese EL, Soulages JL (2010) Insect fat body: energy, metabolism, and regulation. Annu Rev Entomol 55:207-225

24. Wen Z, Pan L, Berenbaum MR, Schuler MA (2003) Metabolism of linear and angular furanocoumarins by Papilio polyxenes CYP6B1 co-expressed with NADPH cytochrome P450 reductase. Insect Biochem Mol Biol 33:937-947

25. Trenczek T, Faye I (1988) Synthesis of immune proteins in primary cultures of fat body from Hyalophora cecropia. Insect Biochem 18: 299-312

26. Pandiarajan J, Jeyarani V, Balaji S, Krishnan M (2016) Silver nanoparticles an accumulative hazard in silkworm: Bombyx mori. Austin J Biotechnol Bioeng 3:1057-1066

27. Wu Y, Zhou Q, Li H, Liu W, Wang T, Jiang G (2010) Effects of silver nanoparticles on the development and histopathology biomarkers of Japanese medaka (Oryzias latipes) using the partiallife test. Aquat Toxicol 100:160-167
28. Cilia M, Fish T, Yang X, McLaughlin M, Thannhauser TW, Gray SA (2009) Comparison of protein extraction methods suitable for gel-based proteomic studies of aphid proteins. J Biomol Tech 20: 201-215

29. Liang Y, Chen H, Tang M, Shen S (2007) Proteome analysis of an ectomycorrhizal fungus Boletus edulis under salt shock. Mycol Res 111:939-946

30. Wu QY, Li F, Zhu WJ, Wang XY (2008) Cloning, expression, purification, and characterization of arginine kinase from locusta migratoria manilensis. Comp Biochem Physiol B Biochem Mol Biol 148:355-362

31. Kang L, Shi H, Liu X, Zhang C, Yao Q, Wang Y, Chang C, Shi J, Cao J, Kong J, Chen K (2011) Arginine kinase is highly expressed in a resistant strain of silkworm (Bombyx mori, lepidoptera): implication of its role in resistance to Bombyx mori nucleopolyhedrovirus. Comp Biochem Physiol B Biochem Mol Biol 158:230-234

32. Vontas JG, Small GJ, Hemingway J (2001) Glutathione stransferases as antioxidant defence agents confer pyrethroid resistance in Nilaparvata lugens. Biochem J 357:65-72

33. Singh SP, Coronella JA, Benes H, Cochrane BJ, Zimniak P (2001) Catalytic function of Drosophila melanogaster, glutathione stransferase dmgsts1-1 (gst-2) in conjugation of lipid peroxidation end products. Eur J Biochem 268:2912-2923

34. Liu J, Wang Z, Liu FD, Kane AB, Hurt RH (2012) Chemical transformations of nanosilver in biological environments. ACS Nano 6: 9887-9899

35. Yu SJ (1992) Detection and biochemical characterization of insecticide resistance in fall armyworm (lepidoptera: noctuidae). J Econ Entomol 85:675-682

36. Kim MY, Song HY, Kim JH, Kim BY, Park SW, Sung DK, Park HH, Jeon SH, Chung IS, Lee BH (2012) Silkworm 30k protein inhibits ecdysone-induced apoptosis by blocking the binding of ultraspiracle to ecdysone receptor-b1 in cultured bm5 cells. Arch Insect Biochem Physiol 81:136-147

37. Park HJ, Kim EJ, Tai YK, Tai HP (2003) Purification of recombinant $30 \mathrm{k}$ protein produced in Escherichia coli, and its anti-apoptotic effect in mammalian and insect cell systems. Enzym Microb Technol 33:466-471

38. Carranco R, Almoguera C, Jordano J (1997) A plant small heat shock protein gene expressed during zygotic embryogenesis but noninducible by heat stress. J Biol Chem 272:27470-27475

39. Sakano D, Li B, Xia Q, Yamamoto K, Banno Y, Fujii H, Aso Y (2006) Genes encoding small heat shock proteins of the silkworm, Bombyx mori. Biosci Biotechnol Biochem 70:2443-2450

40. Haass C, Klein U, Kloetzel PM (1990) Developmental expression of Drosophila melanogaster small heat-shock proteins. J Cell Sci 96:413-418

41. Gallardo M, Barrio S, Fernandez M, Paradela A, Arenas A, Toldos O, Ayala R, Albizua E, Jimenez A, Redondo S, Garcia-Martin RM, Gilsanz F, Albar JP, Martinez-Lopez J (2013) Proteomic analysis reveals heat shock protein 70 has a key role in polycythemia vera. Mol Cancer 12:5429-5438

42. Teufel M, Saudek V, Ledig JP, Bernhardt A, Boularand S, Carreau A, Cairns NJ, Carter C, Cowley DJ, Duverger D, Ganzhorn AJ, Guenet C, Heintzelmann B, Laucher V, Sauvage C, Smirnova T (2003) Sequence identification and characterization of human carnosinase and a closely related non-specific dipeptidase. J Biol Chem 278:6521-6531

43. Licker V, Côte M, Lobrinus JA, Rodrigo N, Kövari E, Hochstrasser DF, Turck N, Sanchez JC, Burkhard PR (2012) Proteomic profiling of the substantia nigra demonstrates cndp 2 overexpression in Parkinson's disease. J Proteome 75:4656-4667

44. Lewit-Bentley A, Réty S (2000) EF-hand calcium-binding proteins. Curr Opin Struct Biol 10:637-643 
45. Gilbert LI, Granger NA, Roe RM (2000) The juvenile hormones: historical facts and speculations on future research directions. Insect Biochem Mol Biol 30:617-644

46. Kramer KJ, Dunn PE, Peterson RC, Seballos HL, Sanburg LL, Law JH (1976) Purification and characterization of carrier protein for juvenile hormone from hemolymph of tobacco hornworm Manduca-Sexta Johannson (Lepidoptera-Sphingidae). J Biol Chem 251:4979-4985

47. Kort CADD, Koopmanschap AB (1987) Specificity of binding of juvenile hormone-III to hemolymph-proteins of Leptinotarsa decemlineata and Locusta migratoria. Cell Mol Life Sci 43:904905

48. Zalewska M, Ozyhar A, Kochman M (2011) Identification of specific interaction of juvenile hormone binding protein with isocitrate dehydrogenase. Acta Biochim Pol 58:119-124

49. Akai H, Kobayashi M (1965) Sites of fibroin formation in the silk gland in Bombyx mori. Nature 206:529-529

50. Balasundaram D, Pradhap M, Vivekananthan T, Mathivanan V (2012) Effect of food supplementation with silver nanoparticles (AgNPs) on feed efficacy of silkworm, Bombyx mori (L.) (lepidoptera: bombycidae). Int J Biol Sci 2:60-67 